\title{
Rakenteen ja kokemuksen komplementaarisuus laadullisen aineiston tulkinnassa ja analyysissa
}

\author{
$+y$ \\ Tietotyön tutkimukseen kaivataan työntekijän kokemukset \\ ja yhteiskunnan rakenteellisen tekijät yhdistävää otetta. \\ Näin saadaan esiin työntekijän ahdistus, joka syntyy \\ odotuksista olla innostunut, luova ja vastuullinen.
}

\section{$\mathbf{y}$}

YKSILÖIDEN TOIMINNAN JA KOKEMUSTEN sekä sosiaalisten ja yhteiskunnallisten rakenteiden suhde on ollut toistuva ongelma yhteiskuntaja ihmistieteissä (ks. esim. Archer 2003; Elder-Vass 2010). Esimerkiksi sosiologiassa metodologiset painotukset ovat vaihdelleet parsonsilaisesta funktionalismista metodologiseen individualismiin. Usein yksilöä ja sosiaalisia rakenteita painottavat näkökulmat ovat metodologisten dualismien jännitekentässä, sidottuna muun muassa kiistoihin siitä, mikä on ihmisen toiminnan selittämisen ja ymmärtämisen välinen ero.
Käsittelemme artikkelissa rakenteen ja kokemuksen välistä problematiikkaa osana hallinnan ja ideologioiden kriittisen tutkimuksen metodologiaa. Taustaoletuksemme on, että jos kyseinen problematiikka ohitetaan tutkimusmetodiikassa ja sen reflektoinnissa, päädytään pahimmillaan erottamaan rakenne ja kokemus toisistaan, mikä johtaa alkuperäisen kysymyksenasettelun kannalta epätarkoituksenmukaisiin päätelmiin. Kysymyksenasettelua tarkentaaksemme analysoimme kahden tutkimusperinteen, ranskalaisfilosofi Michel Foucault'n ajattelua hyödyntävän hallinnan analytiikan sekä psykoanalyyttisen, yksilöllisiä 
YHTEISKUNNALLISESSA

\section{TUTKIMUKSESSA UNOHDETAAN}

\section{LIIAN USEIN IHMISEN}

KOKEMUKSELLINEN

YKSILÖLLISYYS. kenttää; yksilöllisten kokemusten sekä yhteiskunnallis-historiallisten rakenteiden välistä jännitettä. Analysoimme, 1) kuinka on mahdollista löytää komplementaarisia piirteitä kahden tutkimusperinteen välille edellä kuvatussa jännitteessä sekä 2) millaisin ehdoin ja rajoituksin tutkimusperinteiden komplementaarisuus on mahdollista.

\section{Kokemuksen ja rakenteen suhteen tutkiminen - tutkimusprosessin kuvaus}

kokemuksia painottavan tutkimusmetodiikan tarjoamia välineitä rakenteen ja kokemuksen väliseen problematiikkaan tutkimusmetodiikassa. Peilaamme tutkimusmetodologisia koulukuntia toisiinsa ja pyrimme löytämään niistä toisiaan täydentäviä eli komplementaarisia piirteitä. Komplementaarisuus toteutuu 1) soveltamalla hallinnan analytiikan ja psykoanalyyttisen lähestymistavan mahdollisuuksia tutkimusprosessin eri vaiheissa ja 2) peilaamalla niiden tulkintatapoja toisiinsa aineiston tulkinnassa.

Empiirisenä esimerkkinä artikkelimme kysymyksenasettelusta ja siinä esiintyvistä, rakenteen ja kokemuksen välisistä ongelmista käytämme vuonna 2015 julkaistun tutkimuksemme (Nikkola \& Harni 2015) aineistoa. Tutkimuksessa analysoimme yksilöiden kokemuksiksi sisäistyneitä ristiriitoja työyhteisössä ja niiden yhteyksiä laajempiin yhteisöllisiin ja yhteiskunnallisiin ongelmiin etnografisen, erityisesti haastatteluaineiston avulla. Aineistona käyttämämme artikkeli kiinnittyi pitkälti kriittiseen työelämän tutkimukseen. Myös tässä artikkelissa työelämään liittyvä problematiikka toimii kiinnekohtana ja tapausesimerkkinä, joihin peilaamme metodologista pohdintaa kokemuksen ja rakenteen komplementaarisuudesta sekä sen ehdoista.

Kuvaamme ensin tutkimuksemme syntyprosessia, kysymyksenasettelua ja sen haasteita tutkimusmetodologian näkökulmasta. Seuraavaksi esittelemme kaksi kysymyksenasettelun myötä tulleiden haasteiden ympärille rakentuvaa tutkimusperinnettä, hallinnan analytiikan sekä psykoanalyyttisen ja siitä johdetun psykodynaamisen sovelluksen. Lopuksi tarkastelemme, kuinka kahden tutkimusperinteen kautta voidaan lähestyä laajempaa tutkimusmetodologista ongelma-
Artikkelimme laajempana ongelmakenttänä on tutkimusmetodologiassa esiintyvä, yksilön kokemusten ja niitä ympäröivien yhteiskunnallis-historiallisten rakenteiden välinen jännite. Ongelmakenttä on laaja, ja siihen kytkeytyvät jännitteet esiintyvät etenkin yhteiskunta- ja ihmistieteissä. Esimerkiksi kasvatussosiologian voidaan nähdä lähtökohtaisesti tutkivan sitä, miten yhteiskunnan ja yhteisöjen rakenteet ja prosessit määrittävät kasvatusta ja sen käytäntöjä, kun taas kasvatuspsykologian voidaan ajatella tarkastelevan yksilöllisiä merkityksiä ja esimerkiksi sisäisiä oppimisprosesseja. Sosiaalitieteissä kuvattu jännite on kulminoitunut keskusteluun ihmisen toiminnan intentionaalisuudesta (ks. esim. von Wright 1971; Taylor 1965). Esimerkiksi filosofi Juha Varto sessa tutkimuksessa unohdetaan liian usein ihmisen ainutkertainen, kokemuksellinen yksilöllisyys, jota ei voida palauttaa yhteiskunnallisiin rakenteisiin, kuten luokkateorioihin tai parsonilaiseen funktionalismiin (Varto 2005, 5). Esimerkiksi marxilaisessa sosiologisessa tutkimuksessa on taas perinteisesti painotettu ajan hengen (Zeitgeist) ja materiaalisten olosuhteiden ratkaisevaa merkitystä yksilön kokemuskentän muotoutumiselle (ks. esim. Shaw 1985).

Laajemmasta tieteenfilosofisesta näkökulmasta jännite kytkeytyy pitkälti kantilaiseen ajatukseen ihmisen kaksoisroolista maailmassa. Yhtäl̈lä ihminen voidaan nähdä olentona, joka tutkii historiallis-yhteiskunnallista todellisuutta sen ulkopuolelta. Toisaalta historiallis-yhteiskunnallinen aika määrittää aina ihmisen kokemuksia tapoja tutkia maailmaa.

Erityisesti Michel Foucault on käsitellyt tätä jännitettä ihmistieteitä käsittelevissä tutkimuksissaan. on esittänyt huolen siitä, että etenkin yhteiskunnalli- 
Pohjavirtaukset ovat

ORGANISAATION PIILEVI $\ddot{A}$

MERKITYSRAKENTEITA.

Hänen mukaansa ihmistieteillä on erityinen historiallinen tietomuodostuma. Ne ovat paitsi epistemologisesti hauraita myös vakiintumattomia ja historiallisen muutoksen alaisia. Ihminen asettuu ihmistieteiden, kuten taloustieteen, psykologian ja sosiologian, piirissä sekä tiedon subjektiksi että objektiksi. Yhtäältä ihmisen ymmärrys ja kokemus muodostavat ikään kuin tyyssijan ymmärrettävyydelle ja tietoisuudelle. Toisaalta ihmistä ympäröivät asiat, joita hän ei kykene tavoittamaan, mitä voidaan kutsua Foucault'ta mukaillen 'ajattelemattomissa olevaksi'. (Foucault 2010.)

Tutkimuksemme aineisto (Nikkola \& Harni 2015) asettuu edellä kuvattuun tutkimusmetodologiseen jännitekenttään, ja avaa näkökulman siihen, millainen metodologinen prosessi tutkiminen jännitekentässä voi olla. Kokemuksen, etenkin organisaation työntekijöiden "kuuntelun", näkökulma korostui aineistonkeruuvaiheessa, jota ei sidottu tiukasti mihinkään tiettyyn teoreettiseen lähtökohtaan. Sen sijaan aineistonkeruu oli etnografisen observoinnin avulla havaitun, vielä tarkemmin jäsentymättömän, ilmiön piirittämistä. Tutkimuksemme oli osa laajempaa hanketta, jossa hahmotettiin aineistolähtöisesti ilmiötä, työyhteisön pohjavirtauksia. Pohjavirtauksilla tarkoitamme sellaisia organisaation piileviä merkitysrakenteita, joita on vaikea havaita ja yhteisesti sanallistaa, vaikka ne arjen kokemuksina ovat tunnistettuja. Ihminen usein tuntee ristiriidat ennen kuin tunnistaa ne ja ymmärtää niitä (Armstrong 2005).

Ajatus tutkimusaineiston keräämisestä syntyi havainnoista, joita toinen tutkija teki työelämän muutoksesta ja etenkin katvealueista, jotka muutoksessa tuntuivat jäävän sanallistamatta. Aineistonkeruu perustui erityisesti havaintoon, että työyhteisössä oli runsaasti sellaista henkilökohtaista kokemusta, jolle ei ollut tilaa tai paikkaa yhteisön "virallisessa elämässä", vaikka työyhteisöissä näytetään kiinnittävän varsin paljon huomiota kokemuksiin ja yhdessä tekemiseen - ylipäätään avoimeen keskusteluun, kokemusten jakamiseen ja henkiseen hyvinvointiin. Silti monet kokemukset työelämässä tuntuivat olevan vaiettuja - aiheita, joita ei syystä tai toisesta voida käsitellä avoimesti, osana työyhteisön kehittämistä ja arkea.

Laajempi aineistonkeruu nojasi kysymyksiin siitä, millaiset kokemukset jäävät organisaatiossa varjoon tai jopa pimentoon ja miksi joitakin kokemuksia on vaikea kuunnella. Tutkijan ennakko-oletus oli, että työyhteisössä on jotakin sellaista piilevää, olemisen tavoissa ja kielenkäytössä tavoittamatonta, jolla yhteisön elämää tavataan jäsentää.

Havainnoinnin pohjalta tehtiin useita erilaisia haastatteluja, jotka koskivat työyhteisössä syrjässä olemisen kokemuksia, tahtomattaan yhteisöstä pois joutuneiden kokemuksia ja kehittäjien kokemuksia sekä haastatteluja erillisten kiinnostavien episodien pohjalta. Syrjässä olemisen kokemukset valittiin lopulta esimerkkinä käytettävän tutkimuksen pääasialliseksi aineistoksi. Haastattelukysymyksissä oli psykodynaaminen pohjavire. Etnografisen havainnoinnin perusteella tutkimukseen etsittiin haastateltavia, joita pyydettiin kertomaan kokemuksistaan kuulumisesta työyhteisöön ja etenkin syrjässä olemisen kokemuksista. Kysymys lähetettiin kaikille työyhteisön jäsenille, ja haastateltaviksi ilmoittautuivat he, joilla oli aiheesta sanottavaa. Haastattelussa sovellettiin psykoanalyyttiseen perinteeseen perustuvaa Organisation-in-the-Mind-menetelmää, jonka mukaan yksilö muodostaa kuvan organisaatiostaan mieleensä.

Aineistonkeruutapamme tuotti runsaasti työntekijöiden kokemuksia työhön liittyvästä ahdistuksesta ja riittämättömyyden tunteista. Alustavassa analyysissa kävi ilmi, että aineiston ymmärtämiseen tarvittiin sisäisen kokemuksen ymmärtämisen lisäksi teoreettista näkökulmaa, jonka avulla etsiä vastauksia esimerkiksi aineistosta esiin nouseviin kysymyksiin: 1) Miten uusliberalistinen tuloksellisuuspuhe ja tietotyön osittain mahdottomat ehdot sisäistyvät 


\section{YLIOPISTOTYÖST ̈̈ ON}

\author{
UUDEN LAIN MYÖT $\ddot{A}$ TULLUT \\ YH ̈̈ KUORMITTAVAMPAA JA \\ V̈̈HEMM ̈̈N ENNUSTETTAVAA.
}

työntekijöiden kokemuksiksi? 2) Miten yksityiset kokemukset sekä yhteisöllinen ja yhteiskunnallinen merkitys kietoutuvat toisiinsa?

Analyysin tarkentumisen vaihe nosti esiin kysymyksen, missä tietotyössä kulkee oman mielen säätelyn ja laajempien yhteiskunnallisten kysymysten välinen raja. Samalla heräsi työelämän kehittämistä ja työhyvinvointia koskevia kysymyksiä: Mistä asioista yksilön kannattaa, ja täytyykin, ottaa vastuu? Mitkä asiat taas ovat laajempia, eivätkä ratkea työntekijän "mieltä säätämällä"?

Alustavan analyysin jälkeen ryhdyimme kahden tutkijan yhteistyönä kartoittamaan kahden erilaisen lähestymistavan rajamaastoa siten, että keskityimme jäsentämään tietotyöläisten syrässsä olemisen kokemuksia omassa työyhteisössään. Osatutkimukseen valitsemamme haastatteluaineisto toi selkeästi esiin ilmentymiä yhteiskunnallisista ongelmista, jotka kuitenkin nousevat esiin yksilöiden kokemuksina ja joita yksilöt joko tulkitsevat oman mielensä ongelmiksi tai projisoivat ne ympäristöönsä. Näin päädyimme rajaukseen, jossa aineistoa tulkittiin foucault'laisesta hallinnallisuuden ja subjektiviteetin rakentumisen viitekehyksestä. Keskityimme analyysissä tarkastelemaan niin sanottuja minätekniikoita - käytäntöjä, joissa suhdetta itseen pyritään muodostamaan ja kehittämään. Analyysiin palaamme tarkemmin luvuissa "Kokemuksen ja rakenteen komplementaarisuus" sekä "Komplementaarisuuden ehdot".

Tutkimuksemme empiria ja sen analyysi paikantuivat laajempaan keskusteluun muutoksista tietotyön organisoinnissa. Erityisesti on keskusteltu siitä, kuinka vuonna 2010 voimaan tullut yliopistolaki on muuttanut yliopistotyön organisointia ja kuinka työhön on lain myötä tullut managerialismille ominaisia piirteitä. Kriitttisimmissä puheenvuoroissa on paino- tettu muutosten vaikutusta työntekijöiden arkeen: työstä on tullut aiempaa kuormittavampaa ja vähemmän ennustettavaa. Samalla muutoksen on nähty vapauttavan työntekijöiden potentiaalia ja tuottavan näin yhä innovatiivisempaa tutkimusta. (Ks. Jakonen \& Tilli 2011.)

Tutkimuksemme aineistossa tietotyössä tapahtuneet muutokset ja niihin kiinnittyvä keskustelu oli selvästi läsnä. Analyysin pohjalta kuvasimmekin niitä emotionaalisia tilanteita, jotka muodostuvat yhteiskunnassa ja työelämän käytännöissä vallitsevien reunaehtojen pohjalta, mutta jotka tietotyöläiset tulkitsivat lähtökohtaisesti henkilökohtaisiksi ja erityisesti tunneelämän ongelmiksi. Näitä subjektivoituneeseen ja affektiiviseen työhön liittyviä jännitteitä oli ensinnäkin työn tekemisen "vapaus", joka kuitenkin oli tarkasti rajattua. Toinen jännite oli työn ja muun elämän yhteensulautuminen, etenkin työkompetenssin lisääminen ja siitä huolehtiminen myös vapaa-ajalla. Kolmas jännite oli vaatimus työhön liittyvien tunnekokemusten hallitsemisesta ja hyödyntämisestä työssä.

Muuttunut työ ja sen organisoinnin tavat näyttäytyivät siten työntekijöiden kokemuksissa mahdottomana yrityksenä vastata ulkoa asetettuihin vaatimuksiin. Analyysivaiheessa hallinnallisuuden tutkimusperinne muodosti analyysin rungon, ja psykoanalyyttinen jäsentäminen jäi suhteessa hallinnallisuuteen täydentäväksi taustateoriaksi.

\section{KOKEMUKSEN DISKURSIIVISUUS} JA HALLINNAN ANALYTIIKKA

Michel Foucault'n ajattelusta innoituksensa saanut hallinnan analytiikka on viimeistään 1980-luvulta lähtien ollut yhä suositumpi tutkimusmetodologinen suuntaus etenkin yhteiskunta-, sosiaali- ja kasvatustieteiden kentillä. 'Hallinnallisuus' (gouvernementalité) on alun perin Foucault'n (ks. esim. 1991, 225) luoma uudissana, joka viittaa yksilön ulkoisen hallinnan ja itsehallinnan leikkauspisteeseen, yksilölle ulkoisen ja yksilön itseensä kohdistaman vallankäytön yhdistymiseen.

Foucault ei itse kehittänyt hallinnallisuuden ajatusta juuri pidemmälle, mutta myöhemmin siihen perustuvaa analytiikkaa ovat hyödyntäneet ja jatkaneet 
HALLINNAN ANALYTIIKAN

TUTKIMUS ON VALLANK ̈̈YTÖN

TUTKIMISTA.

etenkin sosiologit Peter Miller, Nikolas Rose ja Mitchell Dean. Heidän työssään ovat painottuneet kysymykset taloudellisen elämän hallinnasta, terapeuttisesta auktoriteetista ja kansalaisuuden ihanteista. Näkökulmia yhdistää ensinnäkin sen tarkastelu, miten hallinnallisuus toimii yhteiskunnassa hajautetusti, eli ilman vallankäytön keskuspistettä ja kaiken kokoavaa ohjelmaa tai intentiota. Toiseksi korostetaan sitä, että erityisesti kansanvaltaisissa, avoimissa ja liberaaleissa yhteiskunnissa hallinnallisuutta luonnehtii omanlaisensa refleksiivisyys - hallinnan strategiat pyrkivät rajoittamaan itseään suhteessa yksilöihin. Erityisesti uusliberaalin hallinnan piirissä hallinta pyrkii olemaan pikemminkin mahdollistavaa (enabling) ja yksilön vapautta kunnioittavaa kuin holhoavaa. Kolmanneksi se pyrkii hyödyntämään hallinnassa ihmistieteellistä asiantuntijatietoa. (Miller \& Rose 2010; Rose 1999.)

Hallinnan analytiikan tutkimus on yksinkertaistettuna vallankäytön tutkimista - olkoon vallankäyttö sitten pakottavaa, suostuttelevaa, yksilön vapauden kautta tapahtuvaa tai yksilön itseensä kohdistamaa. Kuten Foucault'n omassa valta-analytiikassa, esimerkiksi tutkimuksissa vankiloiden ja koulujen toiminnasta, hallinnan analytiikassakaan ei niinkään kysytä, miksi tämä tai tuo taho käyttää valtaa vaan miten valtaa konkreettisesti käytetään ja millaisiin yksilöllisiin toiminnan muotoihin tämä johtaa tai millaisia toiminnan ja ajattelun horisontteja tämä yksilöille tuottaa. Näin hallinnan analytiikassa pyritään välttämään yksioikoista kausaliteettia palauttamalla vallan harjoittaminen esimerkiksi luokan tai valtion kaltaisiin, usein epämääräisesti määriteltyihin ilmiöihin. Vallankäyttöä ei mielletä niinkään annettuna ja universaalina tosiasiana vaan jonain sellaisena, jota "kehitetään, muunnetaan ja joka muuntelee ja organisoi" (Pyykkönen \& Kaisto 2010, 10).
Hallinnan tutkimuksessa tarkastellaan myös subjektia ihmistieteellisen tiedon sekä hallinnan kohteena. Kokemuksen käsite on tässä keskeinen. Myöhäistuotannossaan Foucault paikantaa 'kokemuksen' kolmeen toisensa risteävän akselin - tiedon, subjektin ja vallan -leikkauspisteeseen (Foucault 1994; Foucault 1999, 117-120; Clifford 2001, 97-100). Esimerkiksi tietotyön 'kokemus' voidaan nähdä henkilöstöjohtamisen asiantuntijatiedon, työnteon normien ja päämäärien sekä subjektin itsereflektion muotojen suhteena.

Hallinnan analytiikassa subjektin kokemuksen ja institutionaalisten rakenteiden välinen suhde muodostuu lähtökohtaisesti vastavuoroiseksi. Yksilöä tai subjektia kuten ei myöskään valtaa käyttävää tahoa ei siinä ymmärretä universaaliksi, jo olemassa olevaksi tahoksi vaan subjektiviteettiksi, joka rakentuu ja rakentaa itseään, kuten Rose ja Miller kuvaavat:

”Sen sijaan, että kirjoittaisimme itsen tai subjektiviteetin historiaa, tutkisimme yksilöiden suhteita itseemme ja muihin sekä näitä suhteita vastaavia käytäntöjä, jotka olivat samalla noiden suhteiden mahdollisuuden ehtoja ja tekivät mahdolliseksi vaikuttaa näihin suhteisiin. Ei siihen keitä he olivat mutta keitä he ajattelivat olevansa ja keitä he halusivat olla." (Rose \& Miller 2010, 16.)

Subjektien itsehallinnan kuvaus on siis täysin immanenttia, eli subjektivoitumisen käytäntöjen taustalle ei oleteta mitään 'sub-stanssia', esimerkiksi psyyken sisäisiä toimintaperiaatteita, jotka myötävaikuttaisivat tai vastustaisivat hallinnallisuuden ohjelmien sisäistymistä. Hallinnallisuuden tutkimuksessa subjekti on siis eräänlainen 'laskos' (fold, pleat) (Rose 1996; Deleuze 1988), jossa hallinnallisuus on "taitettu" sisäisyydeksi. Metaforan avulla pyritään välttämään hankalat kysymykset yhtältä hallinnan rakenteellisesta ulkopuolesta ja toisaalta sen yksityisestä sisäpuolesta.

Hallinnan analytiikka on monissa yhteyksissä osoittautunut hedelmälliseksi tutkimusmetodologiseksi välineeksi. Nyky-yhteiskunnan hienovaraisten vallan muotojen tutkimuksessa sitä on kuitenkin myös kritisoitu. Kritiikki on kohdistunut etenkin siihen, ettei hallinnan analytiikka minätekniikoiden 


\section{VALTASUHTEET MUODOSTAVAT}

MYÖS AINA VASTARINNAN

MAHDOLLISUUKSIA.

tarkastelussakaan aina kykene tavoittamaan niitä muotoja ja tapoja, joilla yksilöt suhteuttavat itsensä hallinnallisiin regiimeihin, artikkelimme tapauksessa tietotyön organisoinnissa esiintyviin ihanteisiin, tai kuinka he vastustavat niitä (ks. Saari 2016). Esimerkiksi sosiologi Jani Kaisto $(2010,49-71)$ on painottanut, että hallinnan analytiikka keskittyy liiaksi niihin rakenteellisiin ja diskursiivisiin ehtoihin, joita yksilöille ulkoapäin asetetaan. Hallinnan analytiikassa ei Kaiston (mt.) mukaan olekaan riittävästi analysoitu sitä, kuinka yksilöt työstävät itseään näihin ehtoihin sopiviksi ja millaisia merkityksiä he itse niille asettavat.

Edelleen foucault'laista hallinnan analytiikkaa on arvosteltu siitä, että se ei kykene kyllin tarkasti teoretisoimaan niitä mekanismeja, joiden myötä yksilö sisäistää tai on sisäistämättä hallinnallisuuden muotoja, sekä sitä, miten yksilö kykenee muodostamaan vastarintaa näille mekanismeille. Esimerkiksi filosofit Nancy Fraser (1981) ja Jürgen Habermas (1987, 275-295) ovat väittäneet, että foucault'lainen valta-analyysi ei jätä lainkaan tilaa vastarinnan teoretisoinnille eikä normatiivisille näkökulmille sorrosta ja emansipaatiosta. Foucault itse kuitenkin korostaa, että valtasuhteet muodostavat myös aina vastarinnan mahdollisuuksia. Foucault'n mukaan valtaan liittyy eräänlainen "keskipakoisvoima” (Foucault 1979, 52), jonka myötä se tuottaa vastavoimaa. Näin esimerkiksi uudet työn hallinnan käytännöt tuottavat myös strategisia tilanteita, joita voi hyödyntää vastarinnan muodostamisessa. Toisaalla Foucault on painottanut hallinnan tekniikoiden "taktista moniarvoa": ne voidaan tarvittaessa ottaa käyttöön mitä moninaisimpiin, myös vastarinnan, tarkoituksiin (Foucault 1999, 75). Lisäksi yhteiskuntatutkimus on tärkeä toisin kokemisen ja toimimisen tilojen avaajana: se voi tehdä näkyväksi ne normit ja totuuden politiikat, joiden perustalta hallinta tapahtuu ja näin mahdollistaa sen pohtimisen, haluavatko ihmiset tulla hallituksi normien ja totuuden politiikkojen nimissä (Foucault 2007).

Esimerkkitutkimuksemme asetelmalle hallinnan analytiikka tarjosi puitteet tarkastella aiempaa laajemmin niitä ihanteita ja kokemuksen mahdollisuusehtoja, joita nykyinen tietotyö yksilölle asettaa. Tällaisiksi ihanteiksi kuvasimme odotuksia, kuten yrittäjämäisyyttä, sisäistä kontrollia sekä kehon ja mielen hallintaa. Kuten myös Kaisto (2010) on korostanut, näytti kuitenkin siltä, että ainoastaan hallinnan analytiikan tarjoamilla välineillä ei riittävästi kyetä tarkastelemaan niitä muotoja, artikulaatioita, kokemuksia ja vastustamisen tapoja, joita yksilöt antoivat haastatteluissaan laajemmille tietotyötä ja organisaatioita, tapauksessamme yliopistoa, koskeville ehdoille ja ihanteille.

\section{KOKEMUKSEN TUTKIMINEN JA PSYKOANALYYTTINEN NÄKÖKULMA}

Esimerkkitutkimuksessamme yksilöllisten kokemusten tutkiminen muodosti laajemman kehyksen tutkimuksen menetelmävalinnoille. Kokemuksen näkökulmaa hyödynnettiin tutkimuksen eri vaiheissa hieman eri näkökulmista, ja kokemuksia päädyttiin lopulta analysoimaan pääasiassa hallinnan analytiikan pohjalta.

'Kokemuksesta' (experience) on tullut ihmistieteissä keskeinen objektiivisuuden kiinnekohta. Se on subjektille itselleen välitön ja todellinen - kokemuksen 'totuus' ei riipu siitä, minkä kokemus se on. (Scott 1998.) Kokemuksen käsitteellä on juurensa paitsi länsimaisessa tieteenfilosofiassa, jossa se on toiminut objektiivisuuden perustana - varma kokemus on epäilyn tuolla puolen - sekä protestanttisessa teologiassa, jossa sen avulla on korostettu uskon yksilöllistä ja elämyksellistä, sekä politiikasta että uskonnollisista dogmeista riippumatonta luonnetta (Jay 2006; Williams 1983).

Kokemuksen tutkimuksella on niin ikään pitkät perinteet ihmistieteissä, muun muassa historiantutkimuksessa, antropologiassa ja psykologiassa (Scott 1998). Erityisesti 1900-luvun jälkipuolen yhteiskuntatieteiden metodikiistoissa kokemuksesta 
PSYKODYNAAMINEN

OTE HYÖDYNT $\ddot{A} \ddot{A}$

PSYKOANALYYSIIN

PERUSTUVIA MALLEJA.

tuli monien laadullisten tutkimusmetodologioiden polttopiste. Kokemuksen tutkimus sai esimerkiksi haastattelututkimuksessa emansipatorisen luonteen: ensinnäkin kokemusta tutkimalla paljastetaan inhimillisen olemassaolon muotoja, jotka ovat jääneet positivistisena pidetyn määrälisen tai rakenteellisen tutkimuksen varjoon. Lisäksi kokemuksen tutkimus tarjoaa "äänen" yhteiskunnan marginalisoiduille, sorretuille ja vaiennetuille elämänmuodoille. (Baker 1998; Oakley 2001; Kosunen \& Kauko 2016, 28-29.)

Siihen nähden, miten tavallista kokemuksen käyttäminen tutkimuksen empiirisenä lähtökohtana etenkin kasvatus- ja hoitotieteissä on, tutkimuksen empiirisenä lähtökohtana kokemuksen käyttäminen on varsin monimuotoista ja sen myötä hajanaista (esim. Kakkori 2009). Samoin ajatus kokemuksen autenttisuudesta ja siitä, että se kertoo jotakin "todellista" tutkittavan maailmasta, vaikuttaa siihen, millaiseksi kokemus tutkimuksen empiriassa ymmärretään. Lisäksi kokemuksen tutkimisessa tutkijan roolia "tulkinnan välineenä" voidaan pitää erityisenä, koska tutkimus on kahden tai useamman ihmisen välinen suhde: ihmistutkimuksen paras instrumentti on toinen ihminen (Lehtovaara 1994, 11-20, 26-27).

Kokemuksen tutkimuksessa ongelmalliseksi muodostuu toisinaan niin sanotun kaksoishermeneutiikan huomioiminen. Otetaanko huomioon, että haastateltavan kokemukset ovat jo tulkintoja maailmasta vai sulkeistetaanko tämä tulkinnallisuus ja tarkastellaan kokemusta ilman ulkoista referenttiä, esimerkiksi organisaation rakenteita? Ja millä tavalla otetaan huomioon se, että tutkija itse tulkitsee aktiivisesti haastateltavan kokemuksen?
Ongelmaan on tunnetusti olemassa eri lähestymistapoja, joita on hahmotettu muun muassa niin sanotulla emic-etic-erottelulla. (Töttö 2000.) Toisinaan on ajateltu, että tutkijan on kokemusta tulkitessaan pysyttävä mahdollisimman lähellä tutkittavan omaa tapaa kielellistää kokemustaan (emic-tason kieli). Tällöin hän ei vääristä eikä tee muuten väkivaltaa tutkittavan omalle kokemisen tavalle vaan antaa sille tutkimuksessaan "äänen". On myös esitetty, että tutkijan tehtävä ei ole ainoastaan toistaa ja luokitella tutkittavan omaa kokemusta vaan aktiivisesti tulkita sitä esimerkiksi psykoanalyyttisin käsittein. Tällöin tutkija voi "ymmärtää paremmin" tutkittavan kokemusta esimerkiksi tulkitsemalla pintarakenteen alta psykodynaamisen syvärakenteen. Juuri psykoanalyyttinen perinne asettuu tässä mielenkiintoiseen polttopisteeseen, sillä sen lähtökohtana on, että 'kokemuksella' eli sillä, mitä haastateltava pitää välittömästi totena ei ole episteemisesti etuoikeutettua asemaa.

Vaikka on olemassa huomattava määrä yhteiskuntatieteellistä tutkimusta, jossa yksilön kokemusta analysoimalla pyritään tuottamaan ymmärrystä yhteiskunnasta tai yksilön ja yhteiskunnan välisestä suhteesta, kasvatustieteissä kokemusta pidetään usein lähtökohtaisesti psykologisena tutkimuskohteena (esim. Latomaa \& Suorsa 2011; Perttula \& Latomaa 2005), jolloin tulkinnat pysyvät yksilöllisellä tasolla. Ne ovat kuvauksia yksilöiden aikaan, paikkaan ja ruumiiseen sidotusta ainutlaatuisesta subjektiivisesta kokemuksesta, eivätkä suoraan yleistettävissä - tai tulkintoja ei edes yritetä suhteuttaa laajempiin rakenteisiin, joissa kokemukset syntyvät. Esimerkiksi psykoanalyysin ideoiden soveltaminen sosiaalisten ja poliittisten kysymysten tutkimiseen ei kuitenkaan ole uusi ajatus, vaikka soveltaminen ei valtavirtaa olekaan. (Lapping 2011; ks. myös Suorsa 2011.)

Psykoanalyyttisen tutkimuksen kohteena on sen kehittäjästä Sigmund Freudista lähtien ollut ihmisen mieli eli sisäinen todellisuus. Psykoanalyysin näkökulmasta tutkimuksen kohde on kokeva, ajatteleva ja tunteva subjekti. Toinen keskeinen piirre on ihmismielen tiedostamaton ulottuvuus, minkä myötä subjektin käsite monimutkaistuu. Psykoanalyysin 


\section{YKSILÖIDEN SISÄISET}

\section{KOKEMUKSET}

ORGANISAATIOSTA

MUOKKAAVAT ORGANISAATION

TULEVAISUUTTA.

näkökulmasta kysymys, miksi ihminen toimii niin kuin toimii, on oleellinen. Keskeiset metodit subjektin sisäisen todellisuuden tutkimisessa ovat kuuleminen, kuunteleminen ja vuorovaikutukseen pääseminen tutkimuksen kohteen kanssa.

Psykoanalyyttisen koulukunnan sisällä on lukuisia epistemologisia eroja (Lapping, 2011, 6-7). On kuitenkin oleellisempaa etsiä psykoanalyysin yhteyksiä erityisesti yhteiskuntatieteisiin kuin kiistellä sisäisistä eroista:

"Psykoanalyyttiset käsitteet eivät ole tietyn analyysin ulkopuolella esiintyviä yhtenäisiä tai pysyviä objekteja. Ne muotoutuvat analyysiprosessissa, katkonaisessa diskurssissa, ja ovat merkityksellisiä ainoastaan tietyssä sosiaalisessa ja historiallisessa kehyksessä. Käsitteen artikuloiminen on siis käytännöllistä ja saa muotonsa tietyn spesifin tulkinnan kautta, häilyy establisoituneen teoreettisen rakenteen ja ei-merkityksen välillä. Kiinnostavaa on tapa, jolla moninaiset tulkinnan tavat voivat kiinnittyä käsitteeseen."

(Lapping 2011, 6, suomennos Tiina Nikkola.)

1900-luvulla freudilainen psykoanalyysi on yhdistetty myös poliittiseen, erityisesti marxilaiseen teoriaan, jolloin siitä on tullut osa ideologiakritiikkiä (Frosh 1999). Samalla psykoanalyysi on sijoittunut erityisen jännitteiseen tilaan yhteiskuntatieteiden metodologiassa. Toisaalta se on esitetty "emansipatorisen tiedonintressin" (Habermas 1981) edustajana: psykoanalyysin on katsottu auttavan ihmisiä ymmärtämään psyykkisen torjunnan ja alistamisen mekanismeja, näkemään niissä laajempien yhteiskunnallisten ideologioiden rooli ja vapautumaan niistä. Politiikan teorian ja psykoanalyysin yhdistävässä teoriassa onkin pyritty suhtautumaan kriittisesti ja refleksiivisesti psykoanalyyttisen teorian institutionaalisiin kytköksiin ja niiden myötä muodostuviin valtasuhteisiin. Samalla foucault'laisen valta-analytiikan ja psykoanalyyttisen teorian välillä on nähty yhteisiä päämääriä, kuten subjektin tekeminen tietoisiksi niistä tiedon ja vallan rakenteista, jotka ovat muodostaneet ehdot hänen itseymmärrykselleen. Tämä avaa tilan oman itsen uudelleenkuvittelulle. (Ks. esim. Parker 2010.)

Psykoanalyysi on paitsi teoria ja tutkimusmenetelmä myös ihmismielen hoitomenetelmä, ja sen pohjalta on syntynyt laaja kirjo käytännön sovelluksia hoitomuodoista psykodynaamiseen organisaatiokonsultointiin. Psykodynaamisella otteella tarkoitetaan työotetta, joka hyödyntää psykoanalyysiin perustuvia malleja ja teorioita. Esimerkkitutkimuksemme aineistonkeruuvaiheessa hyödynnettiin ensisijaisesti psykoanalyysin psykodynaamista sovellusta. Erityisesti Organisationin-the-Mind-menetelmän perusajatuksia käytettiin niin alkuperäisten, laajempien tutkimuskysymysten ja aineistokeruuvaiheen kuin myös haastatteluasetelman rakentamisessa.

Työyhteisössä yksilö muodostaa kuvan organisaatiostaan mieleensä, ja tämä käsitys vaikuttaa muun muassa hänen työhyvinvointiinsa. Ajattelutapa on kehittynyt työnohjauksessa siitä huomiosta, että organisaatiotaan ja työtään kuvatessaan ihmiset yleensä kuvaavat oman mielensä värittämää merkitysmaailmaa juurikaan tiedostamatta prosessia. Näin syntyvien mielikuvien avulla ihminen kiinnittyy työyhteisöönsä. Yksilöiden sisäiset kokemukset organisaatiosta siis lopulta muokkaavat organisaation tulevaisuutta: ihmiset kiinnittyvät siihen, mitä pitävät arvokkaana ja riittävästi itsensä kanssa sopusoinnussa olevana. (Tokola \& Hyyppä 2004, 39-41.) Kokemukset ja tunteet ovat keskeisiä prosessissa, koska psykodynaamisesti ajatellen ihminen yleensä tuntee ristiriidat ennen kuin ymmärtää niitä tietoisella tasolla (Armstrong 2005). 
TUtKija ANTAa TILAA

TYÖNTEKIJ ÄN OMILLE

OSATTOMUUDEN

KOKEMUKSILLE.

\section{KOKEMUKSEN JA RAKENTEEN KOMPLEMENTAARISUUS}

Alkuperäinen tutkimusaihe, työyhteisön pohjavirtaukset, muotoutui havainnoista, jotka koskevat työelämän muutoksia - tutun muuttumisesta osittain tunnistamattomaksi. Tutkimusprosessi sai alkunsa halusta ymmärtää paremmin tätä tutkijan omassakin arjessa varsin konkreettista ilmiötä. Tutkimusongelma muodostettiin laajentamalla etnografista havainnointia, eräällä tavalla kokemusten laajempaa kuuntelua, kohteeksi valittuun työyhteisöön ja esittämällä kysymyksiä, haastattelupyyntöjä, poimimalla työyhteisössä tapahtuneita kiinnostavia episodeja sekä jäljittämällä niiden syntyä työyhteisön jäseniä haastattelemalla.

Henkilökohtaista kokemusta apuna käyttävää tapaamme muodostaa tutkimusongelma voidaan pitä luonteeltaan psykodynaamisena, tutkimuskohteen havainnointia ja siinä esiintyvien kokemusten "kuuntelemista" laajasti hyödyntävänä. Samoin tutkimusongelman tarkentamisessa hyödynnettiin työnohjauksen ja organisaatioiden tutkivan työotteen piirissä kehitettyjä, psykoanalyyttiseen teoriaperinteeseen nojaavia psykodynaamisia työtapoja.

Esimerkkitapauksessa kokemuksen tutkimuksen psykodynaaminen näkökulma painottui erityisesti aineistonkeruuseen. Lähtökohtana oli tutkijan kiinnostuminen tutkittavien maailmasta. Tutkija antoi tilaa kertomuksille siitä, miten ja millaista osattomuutta tietotyöntekijät kokivat omassa työyhteisössään, ilman että tutkimuksen kannalta kiinnostavia kokemuksia rajattiin tarkemmin ennalta. Näin oli mahdollista nostaa esiin sellaisiakin kokemuksia, joita tutkija ei ollut etukäteen ajatellut kuulevansa.

Tältä osin haastateltavien henkilökohtaiset kokemukset toimivat erityisesti aineiston keräämisen tapana mutta myös lähtökohtana tutkimusongelman muodostamiselle. Työntekijöiden kokemukset kertoivat paitsi heidän sisäisestä maailmastaan myös niistä rakenteista, joissa tietotyötä tehdään.

Tutkimusaineistoa tarkasteltuamme päädyimme pohtimaan artikkelimme keskiössä olevaa kokemuksen ja rakenteen välistä problematiikkaa. Tutkimusongelmaa rajatessamme ja kehystäessämme pohdimme yksittäisen työyhteisön ja siinä toimivien yksilöiden kokemusten suhdetta laajempiin tendensseihin. Sellaisiksi määrittelimme muutokset yliopistomaailmassa ja laajemmin tietotyössä, erityisesti työn muuttumisen affektiiviseksi, yksilöihin yhä vahvemmin kiinnittyväksi, yksilöitä vastuullistavaksi ja heidän tunteitaan hyödyntäväksi.

Kokemuksen kontekstualisoimisen lähtökohtana oli, että yksittäisen organisaation jäsenten kokemusten selittäminen pelkästään sisäisistä lähtökohdista, kuten psykoanalyyttisesta näkökulmasta, ei riitä. Laajemmalla kehystämisellä pyrimme löytämään ennen kaikkea toisiaan täydentäviä näkökulmia yhtäältä psykoanalyyttiseen ja toisaalta usein liian teoreettiseksi jäävään työn tutkimukseen. Näimme toisin sanoen, että yksilölliset kokemukset ja rakenteita painottava työn tutkimus sulautuivat yhteen: laajemmat yhteiskunnalliset tendenssit eivät näyttäneet selittävän yksilöllisiä kokemuksia eivätkä yksilölliset kokemukset tai yksittäisen organisaation toiminta voineet olla ymmärrettävissä puhtaasti niistä itsestään käsin.

Laajemmasta näkökulmasta on myös huomioitu tällainen komplementaarisuus ja etenkin sen puute. On esimerkiksi huomautettu, että "foucault'laisessa tutkimuksessa", kuten hallinnan analytiikassa, ei ole juurikaan tarkasteltu empiirisesti yksilön elämänkäytäntöjä tai kokemuksia (Pyykkönen 2015, 200). Esimerkkitapauksena käyttämässämme aineistossa ja analyysissa voidaankin ajatella olevan kyse juuri sellaisesta valtasuhteiden empiirisestä tutkimuksesta, joka liittyy 


\section{TEORIAPERINTEIDEN}

\section{RISTIRIITAISUUDET OVAT}

\section{MAHDOLLISUUS AINEISTON}

TULKINTAAN.

nyky-yhteiskuntaan ja kytkee rakenteellisen teorian ja käytännön kokemukset toisiinsa. Tietotyöläisten syrässä olemisen kokemukset näyttivät kuvaavan osuvasti henkilökohtaisten kokemusten kautta niitä vallankäytön ilmentymiä, joita haastateltavat vastustavat tai joihin he yrittävät sopeutua.

Henkilökohtaiseen kokemukseen fokusoiminen vaikutti kohdalliselta siksikin, että hallinta on siirtynyt nimenomaan henkilökohtaisen kokemuksen alueelle. Samalla kun hallintavalta pyrki olemaan "mahdollistavaa", se on myös "vastuullistavaa" (responsibilisizing) sikäli, että se vaatii yksilöitä kantamaan itse omaa toimintaansa koskevat riskit. Esimerkiksi työelämän hallinnassa korostetaan yksilön oman työn autonomiaa ja yksilön omaa vastuuta työnsä mielekkyydestä. Siksi hallinnan keskeiset strategiat ja kohteet ilmenevät yksilön "sisäisessä" kokemuksessa. (Miller \& Rose 2010.)

Aineiston analyysissa päädyimme käyttämään Foucault'n (1999) minätekniikoihin liittyvää metodologiaa. Minätekniikoiden kautta analysoimme yksilöiden kokemuksia työyhteisöön liittyvissä ristiriitatilanteissa seuraavasti:

1. Mitä yksilö problematisoi itsessään (eettinen substanssi)?

2. Kuinka haastateltavat suhteuttavat itsensä problematisoituihin osa-alueisiin (alistumisen muoto)?

3. Tekniikat, joilla haastateltavat työstävät itseään organisatorisissa ristiriitatilanteissa.

4. Mikä on se olemisen tapa, johon minätekniikat lopulta pyrkivät (telos)?

Näin kykenimme sekä jäsentämään kokemuksia laajemmasta näkökulmasta käsin että olemaan palauttamatta niitä mihinkään tiettyyn, ennalta määrättyyn sisäisen kokemuksen tulkinnan kehykseen. Minätekniikat antoivat välineitä, joiden avulla komplementaarisuus saadaan esille. Niiden avulla pystyimme jo alustavasti yhdistämään yksilön itseensä kohdistaman problematisoinnin kokemuksen, mahdolliset vastarinnan muodot näitä problematisointeja kohtaan sekä lopulta sen substanssin, johon problematisoinnit ja tekniikat pyrkivät. Tutkimuksen tässä vaiheessa psykodynaaminen ja -analyyttinen näkökulma jäivät taustalle, mutta ajatus näkökulmiemme - yksilöllisen kokemuksen ja rakenteen - välisestä komplementaarisuudesta säilyi edelleen.

Komplementaarisuus toteutui peilaamalla miten- ja miksi-kysymyksiä toisiinsa minätekniikoiden kuvailun sisällä. Käytännössä tarkasteltiin aineistossa kuvattuja henkilökohtaisia, emotionaalisia syrjässä olemisen kokemuksia ja toisaalta niiden liittämistä työelämässä ja laajemmin yhteiskunnassa vallitseviin reunaehtoihin. Sellaisia ovat työn muuttuminen voimakkaasti persoonaan kiinnittyväksi ja sen myötä rajattomaksi sekä yksilön tunteita hyödyntäväksi.

Tämä tarkoitti kahden teoriaperinteen leikkauspinnalla toimimista, aineiston valottamista sekä hallinnan että kokemuksen tutkimuksen suunnista. Kummankin perinteen rajoja venytetään siten, että pääsään alueelle, jossa nämä leikkaavat toisensa ja selittävät aineistoa niiltä osin missä toisen selitysvoima loppuu. Aineistoa ei vain tarkasteltu kahdesta eri näkökulmasta vaan niitä käytettiin analyysin välineenä yhtäaikaisesti. Näin tehtiin, vaikka teoriaperinteet eivät saumattomasti yhdisty vaan nostavat esiin keskenään ristiriitaisiakin näkökulmia aineistoon. Emme vain poimineet teoriaperinteiden analyysin kannalta ensisilmäyksellä soveliaimpia puolia ja tuoneet niitä yhteen vaan näimme juuri näiden teoriaperinteiden ristiriitaisuudet mahdollisuutena aineiston tulkintaan.

Rakenteellisten ristiriitojen sisäistyminen työntekijöiden henkilökohtaisiksi ongelmiksi toi yhteen nämä kaksi näkökulmaa. Yhdessä ne piirsivät laajemman ja monipuolisemman kuvan siitä, mitä organisaatiossa tapahtuu. Kaksoisvalotuksen hyödyllisyyttä kuvaa aineistositaatti, jossa työvoiman 


\section{IHMINEN ITSE EI VOI}

\section{PALJASTAA OMAN \\ KOKEMUKSENSA EHTOJA.}

vähentäminen organisaatiossa lopulta kärjistyy työntekijöiden keskinäiseksi eripuraksi ja jopa epäilyksi työtoverin persoonallisuushäiriöstä:

"Sit siinä tuli jo tämmösiä persoonallisuushäiriöepäilyjä ja muita niinku tähän liittyen ja sit tavallaan niinku johdolle selvis tää kuvio ja se niinku helpotti tai toi semmosta turvallisempaa oloo meidän [lähityöyhteisöön], mut meillon edelleen semmonen tilanne, et väki on hyvin eristäytynyttä ja [--]."

Kun yhdistettiin hallinnan analytiikan miten-kysymys ja psykoanalytiikan miksi-kysymys, löydettiin tietotyön arjen kokemusten tulkintaan rakenteen ja kokemuksen kaksoisvalotus. Filosofit Judith Butler (1997, 84-87) ja Slavoj Žižek (2000) ovatkin esittäneet, että erityisesti psykoanalyyttiset teoriat voivat universalistisen subjektiteoriansa pohjalta hallinnan analytiikkaa paremmin sekä selittää hallinnan sisäistymistä että tuottaa normatiivisen näkökulman vallitsevien hallinnan muotojen kritiikille. Esimerkiksi rakenteellinen ongelma, kuten työvoiman vähentäminen, on luonteeltaan sellainen, että sitä ei voida tulkita pelkästään yksilöiden väliseksi eripuraksi, tai mikäli se niin tulkitaan, ongelman luonne ymmärretään vaillinaisesti.

Miten- ja miksi-kysymysten kautta yksilön kokemus voidaan nähdä paikkana, jossa hallinnan ohjelmat, yksilön ainutlaatuiset elämäntarinat ja psyyken voimat kohtaavat. Tämä tulee esille tutkimuksemme aineistossa hyvin arkisissa ja alun perin henkilökohtaisilta vaikuttavissa kokemuksissa, jotka kuitenkin näkökulmia yhdistelemällä laajenevat yksilöitä rakenteiden tasolla yhdistäviksi.

Esimerkkejä yksilön pyrkimyksistä olla taloudellisesti arvokas ja hyödyllinen organisaatiolle löytyy esimerkkitutkimuksen aineistosta runsaasti ja niiden tulkinta ainoastaan yksilön suunnasta tuntuu riittämättömältä.

"[--] miten saa niinku mahollisimman tehokkaasti irti sitte kirjotusta ja tulosta, kun ei aina ole suinkaan parhaimmillaan [--].”

Työelämästä on viime vuosikymmenten aikana haluttu tehdä itsetoteutuksen ja luovuuden paikka. Onnellinen, hyvinvoiva ja luova työntekijä tuottaa työnantajalle lisäarvoa. Siksi työelämän hallinnan eetos kytkeytyy sisä- ja ulkopuolen problematiikkaan: "ulkoisen" käyttäytymisen - suoritteiden ja indikaattoreiden - hallinta saa helposti pejoratiivisia merkityksiä, kun taas "sisäinen" - luova, ennakoimaton ja innovatiivinen - nähdään uuden talouden keskeisenä lisäarvon lähteenä (vrt. Virtanen 2006). Aineiston kaksoisvalotus nostaa tarkasteluun juuri tämän jännitteen.

\section{KOMPLEMENTAARISUUDEN EHDOT}

Kun puhutaan ihmisten ja heidän kokemustensa tutkimisesta, etenkin tässä hetkessä, tutkija on väistämättä itsekin osa yhteiskunnallis-historiallis-diskursiivista kehystä, jossa kokemukset syntyvät, kerätään ja josta käsin niitä tulkitaan. Tilanne asettaa ehtoja kokemuksen "autenttisuudelle" ja sille, millä tavoin "äänen antaminen" tutkimuskohteelle on mahdollista. Tämä jännite on tullut erityisesti esille Foucault’n ihmistieteiden historiaa koskevassa tutkimuksessa.

Modernien ihmistieteiden piirissä 'kokemus' voi olla empiirisen tutkimuksen kohde, jota tulkitaan suhteessa esimerkiksi hallinnan strategioihin, mutta samalla tutkijan oma 'kokemus', tapa tulkita tutkimuksen kohdetta, on itsessään erilaisten 'rakenteiden' mahdollistama. Tässä kehässä ihminen ei voi paljastaa oman kokemuksensa ehtoja - ne ovat aina osa 'ajattelematonta'. (Foucault 2010.) Foucault'lle psykoanalyysi on omanlaisensa kriittinen tiedonala ihmistieteiden kentällä, sillä se jossain määrin hyväksyy edellä kuvatun ongelman ja liikkuu koko ajan kohti representaation ja kokemuksen ajattelematonta perustaa. (Mt., 348-350.)

Hallinnallisuuden tutkimus on kuitenkin osoittanut, miten psykoanalyyttiset diskurssit toisinaan 


\section{PYRIMME TEKEMÄ̈̈N}

NÄKYVÄKSI KEINOJA,

JOILLA TIETOTYÖLÄINEN

RAKENTAA ITSEÄÄN

ONGELMATILANTEISSA.

kääntävät yhteiskunnan rakenteelliset ongelmat yksilön psyyken ilmiöiksi (Miller \& Rose 2010). Samalla se sisältää länsimaisessa yhteiskunnassa laajalle levinneen tunnustuksen rakenteen, joka tekee yksilön itseymmärryksen riippuvaiseksi vallitsevista asiantuntijadiskursseista ja psykotekniikoista.

Tunnustuksessa yksilö kertoo kokemuksensa psykotieteelliselle asiantuntijalle, joka "tulkitsee" sen ja tarjoaa yksilölle totuuden hänestä itsestään (Foucault 1999; vrt. Fejes \& Dahlstedt 2013). Tunnustavassa sosiaalisessa suhteessa tunnustavan yksilön itseymmärrys ja kokemuksen autenttisuus riippuvat hänelle ulkopuolelta tarjotusta totuudesta. Kokemuksen tutkimukseen sovellettuna voikin kysyä, miten "äänen" antamiseen - vaikka sen tarkoitus olisikin emansipatorinen - sisältyy diskursiivisia ennakkoehtoja, jotka rajaavat sitä, mitä 'ääni' ja 'kokemus' voivat olla, miten niitä voi tunnistaa ja tulkita yhteiskunnallisen tutkimuksen avulla, sekä miten niiden voimaannuttavasta potentiaalista voi ja pitää puhua (Baker 1998). Voidaan kysyä, miten haastattelun usein neutraalin, dialogisen tai emansipatorisen ilmiasun takana on aina epäsymmetrinen suhde, joka ilmenee kommunikaation rajaamisen, tunnustamisen ja tulkitsemisen käytäntöinä (Kosunen \& Kauko 2016).

Useammille tulkintamahdollisuuksille avoin aineistolähtöinen tapa tutkia ihmisten kokemuksia muodostuu usein työlääksi tutkimuksen analyysivaiheessa, kun aineisto ei välttämättä vastaa tutkijan osaamista ja parhaita edellytyksiä suorittaa analyysia. Tutkijalta vaaditaankin sopeutumiskykyä, uudelleenarviointia ja mielikuvitusta, kun aineisto ei tarkalleen vastaakaan sitä, mitä tutkija alun perin oletti tutkivansa. Esimerkkitapauksessa aineistonkeruuvaiheessa keskeinen kokemuksen näkökulma saikin väistyä täydentävään osaan analyysivaiheessa. Kokemuksen tutkiminen ja rakenteellisen hallinnan analyysi olivat siis osittain limittäiset vaiheet, joissa erilaiset lähestymistavat aineistoon osoittautuivat hyödylliseksi tutkimusprosessin edetessä ja lopulta täydensivät toisiaan.

Kriittisyys ja refleksiivisyys esimerkkiaineistomme tulkinnassa perustui osaltaan kahden tutkijan keskenään erilaiseen suhteeseen ja näkökulmaan paitsi taustateoriaan myös aineistoon. Tutkimusaineiston kerääjä oli tiiviissä vuorovaikutuksessa informanttien kanssa, jopa sisäisti ja sulatteli heidän kertomiaan kokemuksia. Tutkimus- ja haastattelumetodin onnistumisen näkökulmasta tätä voi pitää osana tarpeellista vuorovaikutukseen pääsemistä tutkittavien kokemusten kanssa. Psykoanalyyttisin termein kyse on niin sanotusta container-funktiosta, jossa subjekti, eli esimerkkitapauksessa haastateltavat, ulkoistaa itsestään jotakin turvallisena pitämäänsä kohteeseen, joka vuorostaan aktiivisesti ottaa ulkoistetun kokemuksen vastaan. Containerfunktiossa subjektin motiivina on päästä eroon tuskallisena pitämästään asiasta, ja sen alkuperä on lapsen ja vanhemman tunnevuorovaikutuksessa. (Tokola \& Hyyppä 2004, 43; Symington 1996). Ryhmien toimintaa tutkinut psykoanalyytikko Wilfred Bion (1984) alkoi kutsua sijoittavan samastumisen eli projektiivisen identifikaation vastaanottokykyä sisällyttämiskyvyksi (containingfunction).

Tutkittavien kokemuksia "kannattelevan" otteen rinnalle tarvittiin esimerkkitapauksessa toista näkökulmaa, joka myös haastoi psykoanalyyttista tulkintaa. Yhteistyötä kahden tutkijan välillä voidaan pitää oleellisena psykoanalyyttisen ja rakenteellisen tutkimuksen yhdistämisen onnistumiselle. Toisella tutkijalla on kannatteleva rooli. Toinen tutkija taas ei ole samalla tavalla sisällä aineistossa vaan tarkastelee sitä eri näkökulmasta ja tässä tapauksessa myös toisesta teoreettisesta näkökulmasta. Tutkimuksen onnistumisen kannalta sitäkin voidaan pitää hyödyllisenä, että toinen tutkija ei tunne aineiston syntyprosessia. Kun toinen tutkija on aineiston suhteen "sisäpuolella" ja toinen "ulkopuolella", 


\section{Tutkijan oma positio}

\section{EI OLE ITSEST ̈̈̈̈NSELVYYS.}

psykodynaamista metodia voidaan käyttää ilman että tutkittavien ongelmia sisäistetään liian voimallisesti. (Ks. myös Suorsa 2011.)

Yksi artikkelimme keskeisimpiä metodologisia pyrkimyksiä olikin purkaa psykoanalyyttiselle asiantuntijadiskurssille tyypillistä tapaa kääntää laajempia yhteiskunnallisia ongelmia yksilön sisäisiksi ongelmiksi ikään kuin päinvastaiseksi. Pyrimme toisin sanoen komplementaarisen näkökulmamme kautta kuvaamaan 1) tilanteita, joissa laajemmat yhteiskunnalliset, tai vähintään organisatoriset ongelmat näyttivät sisäistyvän yksilön sisäisiksi ongelmiksi sekä antamaan näin ääneen toimijoille 2) olla reduktionistisesti palauttamatta työyhteisössä esiintyvien ongelmien alkuperiä mihinkään yksittäiseen selitysmalliin. Päämäärämme oli ensinnäkin kuvata ja tehdä näkyväksi keinoja, joilla tietotyöläinen rakensi itseään ongelmatilanteissa, haastoi näitä ongelmatilanteita ja toiseksi tehdä subjekti tietoiseksi niistä reunaehdoista, jotka häntä työyhteisössä ympäröivät.

Kolmas mielenkiintoinen metodologinen haaste mutta myös uudenlaista näkökulmaa mahdollistava jännite rakentui sen kysymyksen ympärille, kuinka yksittäinen tapausesimerkki, kuten yhdestä työyhteisöstä kerätty aineistomme, pystyi kuvaamaan laajempia yhteiskunnallisia, etenkin työelämän organisoinnissa tapahtuneita muutoksia. Kuinka kokemus pystyi siis selittämään rakennetta tai kuinka rakenne pystyi selittämään kokemusta? Yksi vastausvaihtoehto kysymykseen voidaan löytää filosofi Giorgio Agambenilta, joka on kyseisen ongelman yhteydessä käyttänyt mielenkiintoisesti paradigman käsitettä. Hän ei viittaa sillä niinkään tieteenfilosofi Thomas Kuhnin tunnetuksi tekemään määritelmään, jossa paradigma viittaa tieteenalan sisäiseen logiikkaan, vaan pikemminkin pyrkimykseen tehdä yksittäisellä tapausesimerkillä ymmärrettäväksi, näkyväksi sekä ylipäätään analysoitavaksi laajempia yhteiskunnallis-poliittisia ilmiöitä. Näin paradigmaattinen esimerkkitapaus ei suoraan ilmaise laajempaa tapausta selittävää ilmiötä eikä ole seuraus mistään laajemmasta ilmiöstä. (Agamben 2002.)

Pyrimme omassa tutkimuksessamme vastaavanlaiseen paradigmaattisuuteen. Esimerkkitapauksena toiminut työyhteisö ja sen dynamiikka ei nähdäksemme voinut olla tyhjentävästi selitettävissä laajemmilla tendensseillä tai etukäteen annetuilla diskursiivisilla ehdoilla, eivätkä yksittäinen työyhteisö ja sen dynamiikka voineet olla analysoitavissa ainoastaan työyhteisöstä itsestään ja siihen kuuluvien yksilöiden kokemuksista käsin.

\section{POHDINTA}

Olemme artikkelissamme tuoneet uudenlaista ja yhdistelevää tutkimusmetodologista näkökulmaa rakenteiden ja kokemusten välisten jännitteiden kuvaamiseen. Selventääksemme tätä käytimme esimerkkeinä kahta tutkimusmetodologista perinnettä, hallinnan analytiikkaa, psykoanalyyttista kokemusten tutkimusta sekä omaa tutkimustamme (Nikkola \& Harni 2015).

Esitimme ensinnäkin, että tutkijan oma positio ja sen myötä emansipatorinen pyrkimys "äänen" antamiselle ei ole itsestään selvää. Toisekseen komplementaarisuutta hyödyntävän tutkimusprosessin kulkua on vaikea ennustaa, ja se vaatiikin tutkijalta kykyä sopeuttaa suunnitelmiaan prosessin edetessä. Lisäksi on pohdittava, millä ehdoilla ja miten yksittäisellä tapausesimerkillä voidaan tehdä ymmärrettäväksi, näkyväksi ja ylipäänsä analysoitavaksi laajoja yhteiskunnallis-poliittisia ilmiöitä. Vielä on syytä pohtia, voisiko "ahdistus" kokemuksena ja "äänen antaminen ahdistukselle" tutkimuksessa toimia vähintäänkin kokemuksen ennakkoehtojen koetteluna ja kenties jopa mahdollisuutena ylittää nuo ennakkoehdot.

Käyttämämme esimerkki osoittaa, että ainakaan kaikissa tapauksissa tutkimusmetodiikka 


\section{TYÖELÄMÄSTÄ ON}

\section{MUODOSTUNUT LUOVUUDEN,}

ITSEOHJAUTUVUUDEN JA

ITSETOTEUTUKSEN PAIKKA.

ei ole palautettavissa pysyviin ja yleispäteviin käytännöllisiin ohjeisiin. Menetelmien osaaminen on enemmänkin teoreettiseen ymmärrykseen perustuvaa jatkuvaa järkeilyä kulloinkin vallitsevien yhteisöllisten ja yhteiskunnallisten reunaehtojen asettamissa rajoissa. Valmiin menetelmän avulla saavutetaan jossakin määrin ennalta-arvattava tulos: tutkija näkee sen, mitä valittu metodi näyttää. Ilmiöiden selittäminen muuttuvissa tilanteissa vaatii jossakin määrin myös menetelmien pitämistä avoimina.

Lisäksi artikkelimme analyysi kuvaa nykyisen työelämän tutkimuksen kentälle muodostuvaa jännitettä ja haasteita. Työelämästä, etenkin tietotyöstä ja sen organisoinnista, on useiden analyysien valossa muodostunut luovuuden, itseohjautuvuuden ja itsetoteutuksen paikka (ks. esim. Brunila ym. 2015; vrt. Virtanen 2006). Tämä perustuu näkemykseen siitä, että onnellisen, hyvinvoivan ja luovan työntekijän oletetaan olevan tyytyväisempi työoloihinsa mutta myös siihen, että tällainen työntekijä tuottaa työnantajalleen enemmän lisäarvoa (Binkley 2014). Siksi nykyinen työelämän hallinnan eetos kytkeytyy pitkälti artikkelissamme kuvattuun sisä- ja ulkopuolen väliseen problematiikkaan. Tämä näkyy erityisesti siten, että ulkoisen käyttäytymisen - esimerkiksi suoritteiden ja indikaattoreiden - hallinta saa helposti pejoratiivisia merkityksiä, kun taas" sisäinen" - esimerkiksi luova ja ennakoimaton - nähdään uudessa taloudessa ja työn organisoinnissa keskeisenä lisäarvon lähteenä.

Edellä kuvattu jännitekenttä luo uudenlaisia haasteita etenkin työelämän kriittiselle tutkimukselle (Boltanski \& Chiapello 2005). Kritiikki työtä ja sen organisointia kohtaan ohjautuu usein helposti oikosuluksi, jossa kritiikin esittäjä voi ainoastaan katsoa peiliin: Miksi et haluaisi olla luova? Etkö halua ottaa vastuuta omasta työstäsi?
Näissä haasteissa kaivataankin uudenlaista kokemuksen tutkimuksen metodologiaa ja analyysia: sellaista, joka kykenee antamaan "äänen" ahdistukselle, joka syntyy peitellystä pakosta olla innostunut, luova, yksilöllinen ja vastuullinen hallinnan tekniikoiden ennalta määrätyllä tavalla. Juuri tällaisessa tilanteessa kuvaamamme kokemuksen ja rakenteiden välinen komplementaarisuus työelämän tutkimuksessa on nähdäksemme tarpeellinen. Lisäksi se avaa uusia näkökulmia työelämän hallintaa koskevaan problematiikkaan.

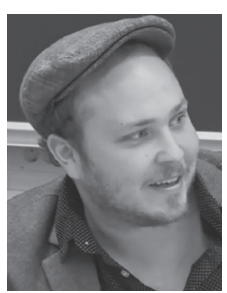

ESKO HARNI

YTM, KM, väitöskirjatutkija kasvatustieteiden tiedekunta Tampereen yliopisto

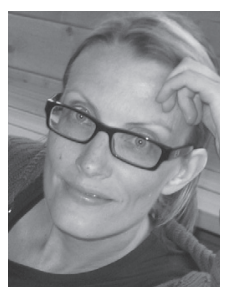

TIINA NIKKOLA

KT, FM, yliopistonopettaja kasvatustieteiden ja psykologian tiedekunta Jyväskylän yliopisto

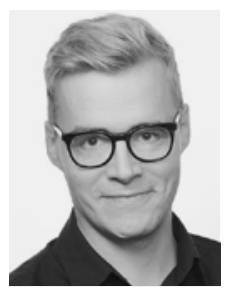

ANTTI SAARI

KT, dosentti, yliopistotutkija kasvatustieteiden tiedekunta Tampereen yliopisto 
Agamben, G. (2002). What is paradigm? http://www. maxvanmanen.com/files/2014/03/Agamben-What-isa-paradigm1.pdf.

Archer, M. S. (2003). Structure, Agency and the Internal Conversation. Cambridge: Cambridge University Press.

Armstrong, D. (2005). Organization in the Mind. Psychoanalysis, Group Relations, and Organizational Consultancy. London: Karnac.

Baker, B. (1999). What is voice? Issues of identity and representation in the framing of reviews. Review of Educational Research, 69 (4), 365-383.

Bion, W. R. (1984 [1963]). Elements of Psycho-analysis. London: Karnac.

Boltanski, L. \& Chiapello, E. (2005). The new spirit of capitalism. International Journal of Politics, Culture, and Society, 18(3-4), 161-188.

Butler, J. (1997). The Psychic Life of Power: Theories in Subjection. Stanford University Press.

Clifford, M. (2001). Political Genealogy after Foucault: Savage Identities. New York: Routledge.

Deleuze, G. (1988). Foucault. London: Continuum.

Elder-Vass, D. (2010). The Causal Power of Social Structures: Emergence, Structure and Agency. Cambridge: Cambridge University Press.

Fejes, A. \& Dahlstedt, M. (2013). The Confessing Society: Foucault, Confession and Practices of Lifelong Learning. London: Routledge.

Foucault, M. (1979). Power, Truth, Strategy. Sydne: Feral Publications.

Foucault, M. (1991). Governmentality. Teoksessa Burchell, g., Gordon, c. \& Miller, P. (toim.) The Foucault Effect: Studies in Governmentality. Chicago: University of Chicago Press, 87-104.

Foucault, M. (1994) Foucault [kirjoitettu salanimellä Maurice Florence) Teoksessa Dits et écrits IV. Paris: Gallimard, 631-636.

Foucault, M. (1999). Seksuaalisuuden historia. Helsinki: Gaudeamus.

Foucault, M. (2007). What is critique? Teoksessa Lotringer, S. (toim.) The Politics of Truth. Los Angeles: Semiotext(e), 41-81.

Foucault, M. (2010). Sanat ja asiat: Eräs ihmistieteiden historia. Helsinki: Gaudeamus.

Fraser, N. (1981). Foucault On Modern Power: Empirical insights and Normative Confusions. Praxis international, 1(3), 272-287.

Habermas, J. (1981). Tieto ja intressi. Teoksessa Tuomela, R. \& Patoluoto, I. (toim.) Yhteiskuntatieteiden filosofiset perusteet I, 118-141.
Habermas, J. (1987). The Philosophical Discourse of Modernity. Cambridge: Polity Press.

Herman, E. (1995). The Romance of American Psychology: Political Culture in the Age of Experts. Berkeley: University of California Press.

Jakonen, M. \& Tilli, J. (2011). Yhteinen yliopisto. Helsinki: Tutkijaliitto.

Jay, M. (2005). Songs of Experience. Modern American and European Variations on a Universal Theme. University of California Press, Berkeley.

Kaisto, J. (2010). Kääntämisen sosiologia hallinnan analytiikan työkaluna. Teoksessa Pyykkönen, M. \& Kaisto, J. (toim.) Hallintavalta. Helsinki: Gaudeamus.

Kakkori, L. (2009). Hermeneutiikka ja fenomenologia. Hermeneuttisfenomenologisen tutkimusotteen sisäisestä problematiikasta. Aikuiskasvatus 29 (4), 273-280.

Kosunen, S. \& Kauko, J. (2016). Valtasuhteet tutkimushaastattelussa. Politiikka 58 (1), 27-40.

Lapping, C. (2011). Psychoanalysis in Social Research. Shifting Theories and Reframing Concepts. London and New York: Routledge.

Latomaa, T. \& Suorsa, T. (2011). Kokemuksen tutkimus II. Ymmärtävän psykologian syntyhistoria ja kehityslinjoja. Rovaniemi: Lapin yliopistokustannus.

Lehtovaara, M. (1994). Fenomenologinen näkökulma ihmisen tutkimisen metodologiaan. Teoksessa Varto, J. (toim.) Kohti elämismaailman ja ihmisen laadullista tutkimusta 1 \& 2. uudistettu ja laajennettu laitos. Tampere: Suomen fenomenologinen instituutti, 3-32.

Miller, P. \& Rose, N. (2010). Miten meitä hallitaan. Tampere: Vastapaino.

Nikkola, T. \& Harni, E. (2015). Sisäistyneet ristiriidat, tunnetyö ja tietotyöläissubjektiviteetin rakentuminen. Aikuiskasvatus 35 (4), 244-253.

Oakley, A. (2000). Experiments in Knowing. Gender and Method in the Social Sciences. Cambridge: Polity Press.

Perttula, J. \& Latomaa, T. (2005). Kokemuksen tutkimus. Merkitys -tulkinta - ymmärtäminen. Helsinki: Dialogia.

Pyykkönen, M. (2015). Michel Foucault - Tiedon, vallan ja subjektiuden tutkija Teoksessa Pyykkönen, M. \& Kauppinen, I. (toim.) 1900-luvun ranskalainen yhteiskuntateoria. Helsinki: Gaudeamus,

Rose, N. (1999). Powers of Freedom: Reframing Political Thought. Cambridge: Cambridge University Press.

Rose, N. (1996). Inventing Our Selves. Psychology, Power, and Personhood. Cambridge: Cambridge University Press. 
Saari, A. (2016). Elinikäinen oppiminen ja yksilöivä valta. Aikuiskasvatus 36 (1) 4-13.

Scott, J. (1992). Experience. Teoksessa Butler, J. \& Scott, J. W. (toim) Feminists Theorize the Political. London: Routledge, 22-40.

Shaw, M. (1985). Marxist Sociology Revisited: Critical Assessments. Palgrave Macmillan.

Suorsa, T. (2011). Kokemuksen yksilöllisyys, yhteisyys ja yhteiskunnallisuus. Subjektitieteellisestä kokemustutkimuksesta. Teoksessa Latomaa, T. \& Suorsa, T. Kokemuksen tutkimus II. Ymmärtävän psykologian syntyhistoria ja kehityslinjoja. Rovaniemi: Lapin yliopistokustannus, 174-231.

Symington, J. \& Symington, N. (1996). The Clinical Thinking of Wilfred Bion. New York: Routledge.

Taylor, C. (1965). The Explanation of Behaviour. London: Routledge \& Kegan Paul.

Tokola, P. \& Hyyppä, H. (2004). Konsultaatiotyön perusteita. Oulu: Metanoia instituutti.

Töttö, P. (2000). Pirullisen positivismin paluu. Tampere: Vastapaino.

Varto, J. (2005). Laadullisen tutkimuksen metodologia. http://arted.uiah.fi/synnyt/kirjat/varto_laadullisen_ tutkimuksen_metodologia.pdf

Williams, R. (1983). Keywords. A Vocabulary of Culture and Society. Oxford: Oxford University Press.

Wright, G. H. v. (1971). Explanation and Understanding. Ithaca (N.Y.): Cornell University Press.

Virtanen, A. (2006). Biopoliittisen talouden kritiikki. Helsinki School of Economics.

Žižek, S. (2000). The Ticklish Subject: The Absent Core of Political Ontology. London: Verso. 